\title{
Human energy
}

\author{
Suzana Sawyer
}

(C) The Author(s) 2009. This article is published with open access at Springerlink.com

\begin{abstract}
In the midst of big-oil record profits and growing debate on global warming, the Chevron Corporation launched its "Human Energy" public relations campaign. In television commercials and print advertisements, Chevron portrays itself as a compassionate entity striving to solve the planet's energy crisis. Yet, the first term in this corporate oxymoron misleadingly reframes the significance of the second, suggesting that the corporation has a renewed focus. In depicting Chevron as a green/human organization, the "Human Energy" campaign obscures from view the corporation's more unsightly products, policies, and practices. Reflection, however, on our own complicity in sustaining energy corporations and their activities undermines binary thinking and signals that the compulsion to denounce is insufficient. This article explores Chevron's media campaign and one organized reaction to it. This counter-campaign both redeployed Chevron's imagery and underscored our collusion and responsibility-tactics seeking to loosen the taut inevitability-of-oil story at Chevron's core.
\end{abstract}

Keywords Chevron - Ecuador - Oil - Politics of denunciation · Politics of implication · Public relations · Corporate oxymoron

Across a blackened screen appear the words "Tapped energy." Soon they morph into "Untapped energy." The words fill the mind, rhythmically pulsating through a compelling score. The visual images are raw, direct, open. A two-minute television commercial by the Chevron Corporation has just begun. Experience the power of "Human Energy":

\footnotetext{
S. Sawyer $(\bowtie)$

University of California, Davis, CA, USA

e-mail: smsawyer@ucdavis.edu
} 
And outside, the debate rages. Oil. Energy. The Environment. It is the story of our time, and it is definitive and all encompassing. And it leaves no one untouched. Because make no mistake, this isn't just about oil companies, this is about you and me. And the undeniable truth that at this moment there are 6.5 billion people on this planet, and by year's end there will be another 73 million. And every one of us will need energy to live. Where will it come from? This is Chevron's challenge each day. Because for today and tomorrow and the foreseeable future, our lives demand oil. But what's also true is that we can provide it more intelligently, more efficiently, more respectfully, that we'll never stop looking for alternatives, that an oil company can practice and espouse conservation. Yes, we are an oil company, but right now we are also providing natural gas, solar, hydrogen, geothermal. Because we live on this planet too. This is who we are, in 180 countries. Not corporate titans. But men and women of vision. Fifty-eight-thousand citizens of the world. Liberals and conservatives. Engineers and scientists. Pipeline welders and geologists. Husbands and wives. Part-time poets and coaches. Peoples who daily try to find newer ways, cleaners ways, to power the world. Humans have always reached for what seemed impossible. Because it is then that we find a way. Tell us it can't be done. Then watch as we tap the greatest source of energy in the world-ourselves.

Against a white backdrop, the word "oil" quickly morphs into "geo-thermal" then "solar," "natural gas," "hydrogen," "conservation," and finally "CHEVRON." The narrator's voice returns: "This is the power of human energy."

In September 2007, in the midst of record-breaking profits and a growing global debate on energy consumption, and global warming, the Chevron Corporation launched its "Human Energy" campaign. Through a multi-million dollar publicity campaign, Chevron - a globally integrated energy company whose business encompasses every facet of the petroleum and natural gas industries-presents itself as a caring entity striving to solve the world's energy crises through the power of human creative forces.

Chevron is the second largest oil company in the United States, and the fourth largest in the world-trumped only by Exxon, Shell, and BP. What does it mean when a petroleum corporation personifies and humanizes itself as working in the service of humanity ("This is who we are. Not corporate titans. But men and women of vision")? What sorts of distinctions are made and unmade when a corporation takes on and subtly reframes the questions of its critics ("Oil, energy, the environment. It is the story of our time")? How are geographies of inequality, risk, and accountability transformed through emotive cinematography and narrative that situate the energy crisis at the global level ("And the undeniable truth that at this moment there are 6.5 billion people on this planet.... And every one of us will need energy to live.") — and its solution in the individual ("Tell us it can't be done. Then watch as we tap the greatest source of energy in the world-ourselves")?

Chevron's "Human Energy" campaign consists of a number of TV commercials and print advertisements showcased in magazines and on billboards across the U.S. and beyond. In this essay, I reflect on this public relations makeover, focusing on the 
television spot (first aired during "60 Minutes" on September 30, 2007), print advertisements, and one dimension of the organized reaction to Chevron's media campaign.

Shot in 22 locations in 13 countries over a 3-months period, "Untapped Energy" reflects a polish and emotion rarely captured by an oil company. A New York advertising agency, McGarryBowen, produced the effect, using the cinematography of Lance Acord (of "Lost in Translation" and "Being John Malkovich" fame), the musical score of Paul Leonard-Morgan (a young UK composer), and the voice of Campbell Scott (an acclaimed indie actor). With its rough sleekness, its documentary grit and grip, "Untapped Energy" has more the feel of a rallying cry of compassion than a market-oriented advertisement by a beneficiary of economic liberalization.

Human energy Like the Orwellian Newspeak that Peter Benson and Stuart Kirsch discuss in the introduction to this forum, the first term reframes the significance of the second, lending the corporation a renewed focus. "Human Energy"embodied ingenuity inherent in every individual-not hydrocarbon fuel, we are asked to recognize, is really at the core of Chevron's business. Yet, in framing the corporation as a human organization determined to work for our planet, the "Human Energy" campaign fades out lived realities and abiding revenue streams that the corporation would prefer its viewers not see. A cluster of NGOs concerned with climate change and environmental responsibility has roundly debunked the "Human Energy" ads as a case of "greenwashing." To that we might add "fleshwashing" that is, by showcasing environmental and humanistic commitment the commercials seek to conceal the corporation's more unsightly products, policies, and practices.

No doubt many lovely people work for Chevron-be they part-time poets or coaches. Human energy is an important part of what makes the company tick. However, the vast majority of Chevron's employees do not make corporate decisions. A handful of directors and executive managers do and are bound by their fiduciary responsibility to shareholders. And while many individuals within the corporation may be earnestly committed to resolving our future energy dilemmas, Chevron has obscured from view the fact that many others around the world find it woefully incapable of doing just that. Their experience stands as a gnawing reminder of how unkind the corporation's activities have been socially, economically, and environmentally.

In 2008, a class action lawsuit, Bowoto v. Chevron, in the San Francisco District Court alleged that Chevron had violated human rights and destroyed natural ecosystems in Nigeria's Niger Delta region. In early December 2008, a jury exonerated Chevron of all claims. However, the decision-surely to be appealedarguably exposed the difficulty of suing a transnational entity in the U.S. for abuses overseas as much as it offered a pronouncement on Chevron's practices. Another lawsuit, Aguinda v. Chevron, is currently underway in an Ecuadorian Superior Court where Chevron is being sued; Texaco Inc., which it bought in 2001, is alleged to have knowingly contaminated the environment and endangered the health of peoples in the Northern Ecuadorian Amazon. Opposing parties expect the Ecuadorian judge to rule on the case by the end of 2009, 15 years after it was first filed in the New York federal court. The practices that these (and other) 
litigations seek to condemn are not isolated, but part and parcel of how many oil operations have been carried out around the world.

Although it is unlikely that Chevron's advertisements will significantly change individual views of Big Oil, the campaign does have the possibility of shifting the debate. Juxtaposing environmental concerns ("And outside, the debate rages. Oil. Energy. The Environment. It is the story of our time") with the more immediate "undeniable truths" of population explosions and its accompanying demand for more energy, the Chevron ads make clear that renewable sources, while complementary, are not a panacea: "Because for today and tomorrow and the foreseeable future, our lives demand oil." Hydrocarbon fuels are both necessary and inevitable. End of discussion. Well, almost. For, "what is also true is that we can provide [oil] more intelligently, more efficiently, more respectfully... that an oil company can practice and espouse conservation." Both green and flesh edge their way back onto the legitimacy score-board.

At stake is not simply the possibility of winning over more consumers through the banding of Chevron petroleum products as environmentally and socially friendly. I suspect the majority of consumers buy their gasoline where they deem most convenient, weighing time, traffic, and cost concerns. Rather, the way Chevron positions the issues and promotes a reasonable solution eases the mind of consumers. And this embellishes-as Robert Foster (2007) reminds us-that more intangible commodity that Chevron seeks to sell: its stock. However, unaccounted for in the "Human Energy" campaign is the harm caused not only in getting, but also in burning, Chevron's fossil fuels. Much like the cigarette that Peter Benson analyzes, hydrocarbons "injure" as a matter of course when consumed as intended.

Yet, something more is going on with the "Untapped Energy" commercial. It evokes a logic of sensation that exceeds its story. Gilles Deleuze (2003) suggests that sensations that hit the body, directly affecting the neurological system without passing through the analytics of the brain, both reverberate sentiments of dominant forms and open up possibilities for things to be otherwise-for different sensibilities of the world to catch hold. They flood in instants of enactment and composition, and may, as with Chevron's television commercials, be the effect of highly scripted choreography to evoke a blush of caring, commitment, and exhilaration. Yet, they also invoke senses of rhizomatic entanglements, of sentient participation and unwitting support that blur clear divisions (i.e., good guys/bad guys) by surfacing questions of involvement and responsibility. Chevron is right: at this moment, at this time, at this particular historical conjuncture, we in the over-consuming hyperspaces of an ever-precarious modernity do depend on the extraction of hydrocarbons to fuel our world. Complicity invites reflection. It also suggests that the compulsion to denounce, rather than inspect the relationships we sustain with and through Chevron and oil more generally, is insufficient.

On May 27, 2009, the day of Chevron's Annual General Meeting (AGM), hundreds of people gathered in front of Chevron's headquarters in San Ramon, California, to denounce a number of the corporation's practices. The protest encompassed two wider forms of engagement: an initiative to subvert Chevron's Human Energy campaign and an initiative to embrace the position of stockholders. 
The first strategy redeployed the print advertisement component of Chevron's Human Energy campaign which similarly seeks to trigger a logic of sensation that invokes a blush of caring, commitment, and integrity. Appearing in magazines and on billboards, these ads depict close-up face shot of diverse, thoughtful individuals with a personalized commitment chalked across their image: "I will use less energy"; "I will leave the car at home more"; "I will turn stuff off more." Beside them is small print-copy of Chevron's commitment to do the same: "And we will too. The world demands more and more energy. Where will it come from? We at Chevron are working to provide more of it, both responsibly and efficiently...." (Figs. 1 and 2).

In response to these ads, in the Spring 2009, members of Amazon Watch-a California-based environmental and indigenous rights group-spearheaded an "InHumane Energy" campaign. Deploying what activists call "subvertisement," the campaign decries Chevvrong [sic] and its practices around the globe, especially in Ecuador where Amazon Watch has sustained a multifaceted and critical effort in support of the plaintiffs suing Chevron for alleged environmental contamination and its effects. Against the backdrop of similar kind and earnest portraits, chalky script proclaims: "I will try not to have a miscarriage"; "I will ignore the toxic waste pits in my village"; "I will try not to get cancer." Along side the faces is print-copy that reads: "Chevron's toxic dumping in Ecuador causes miscarriages, birth defects and cancer" or "Chevron dumped over 18 billion gallons of toxic waste into the Amazon. Learn more at TrueCostofChevron.com" (Figs. 3 and 4).

Outside Chevron's gated headquarters, these and other subvertisements filled the lawn as a coalition of protesters greeted early morning shareholders arriving to

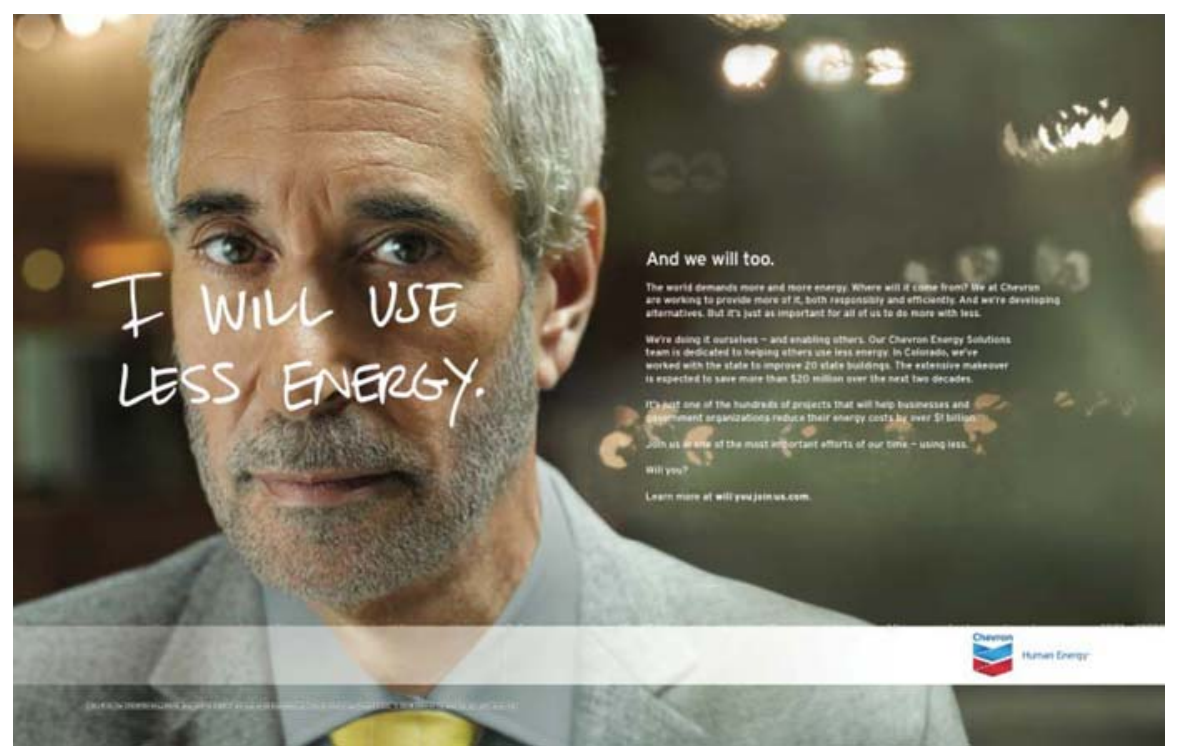

Fig. 1 "I will use less energy." One of Chevron's Human Energy print advertisements (http://www. chevron.com/about/advertising/\#b2) 


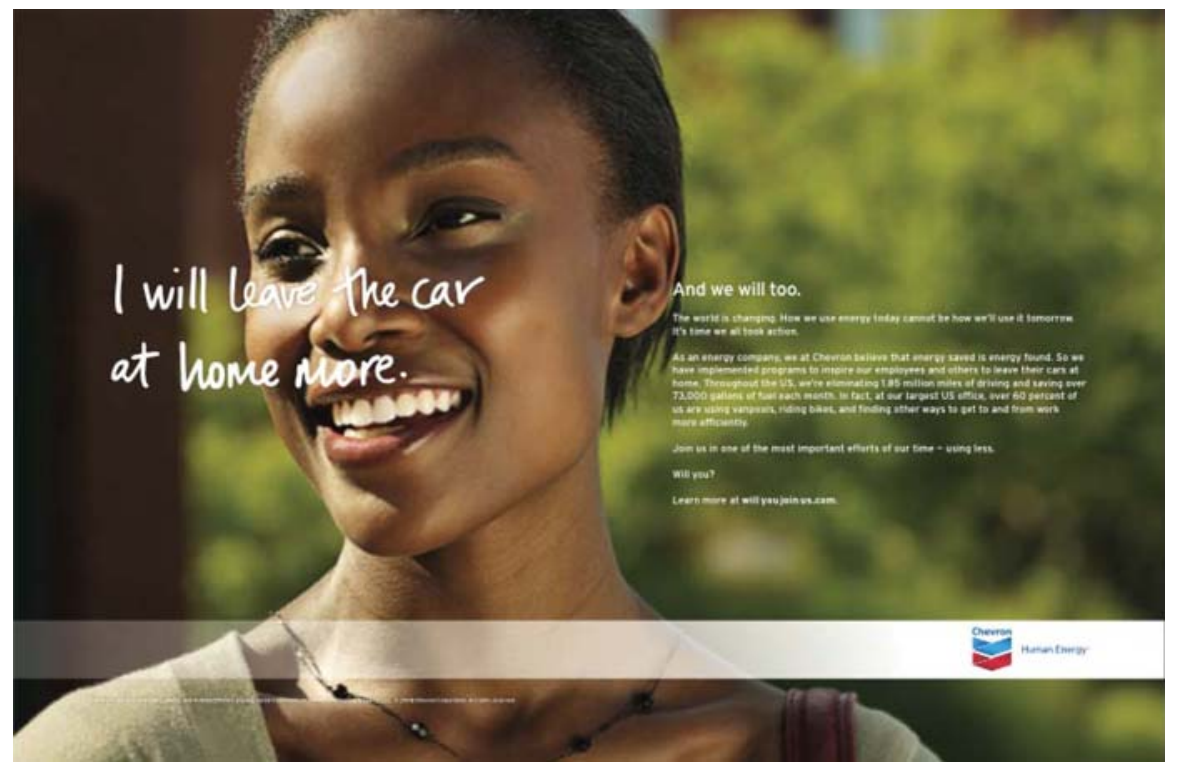

Fig. 2 "I will leave the car at home more." Another Human Energy print advertisements (http://www. chevron.com/about/advertising/\#b2)

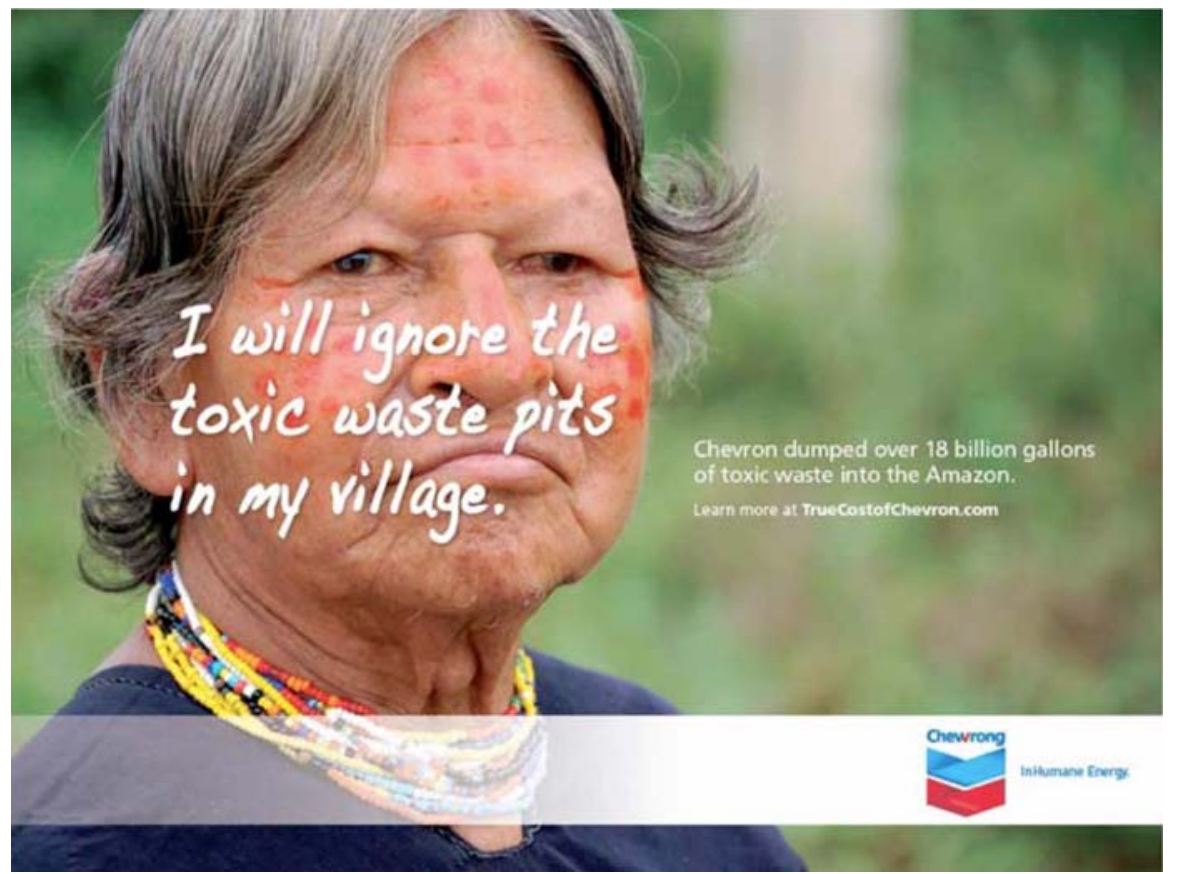

Fig. 3 "I will ignore the toxic waste pits in my village." One of Amazon Watch/True Cost of Chevron coalition's Inhumane Energy "subvertisements" (http://truecostofchevron.com/ecuador.html) 


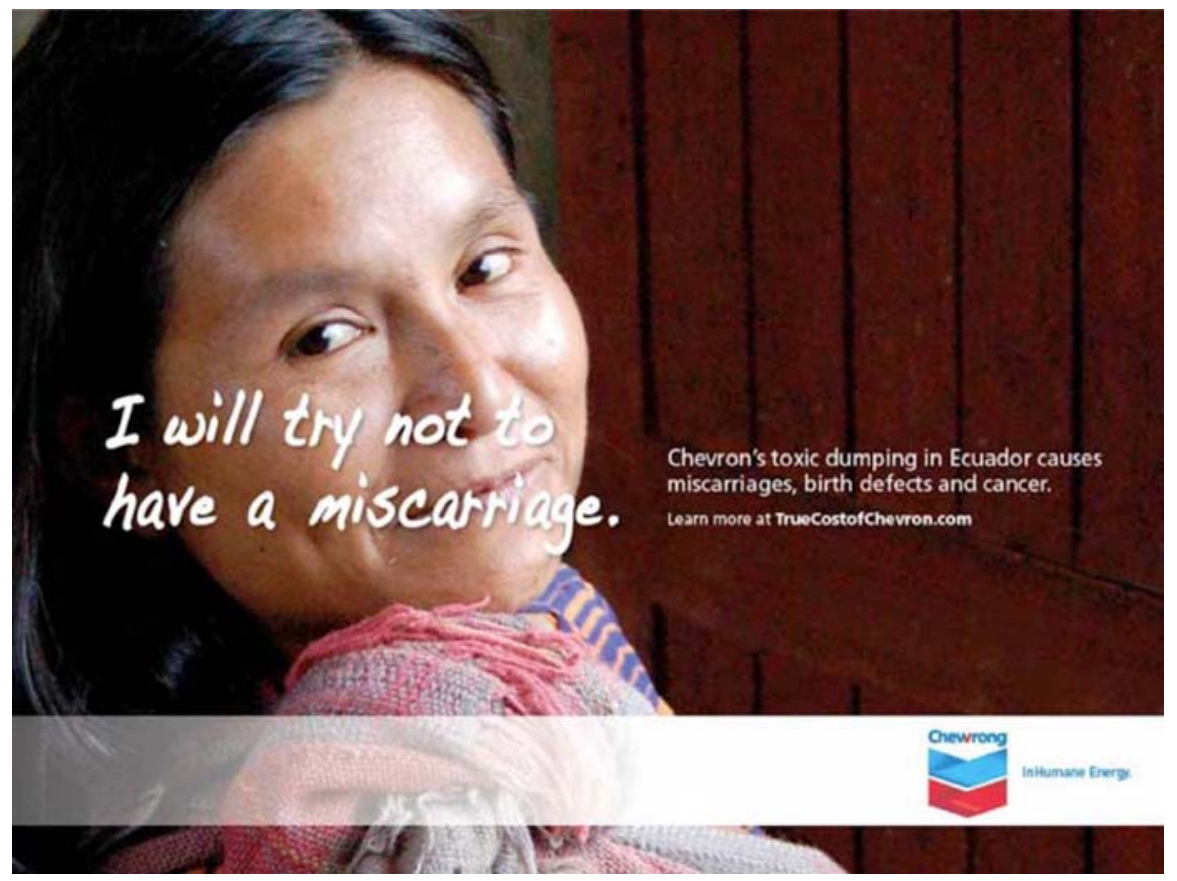

Fig. 4 "I will try not to have a miscarriage." Another Inhumane Energy "subvertisements" (http://true costofchevron.com/ecuadors.html)

attend the corporation's AGM. A billboard picturing the smiling face of Chevron's CEO, Bill O'Reilly, read, "I will pretend to care about the environment" against thick smoke billowing from a refinery. Another depicted a portrait by Lou Dematteis of a man in his early 40 s dying from cancer in the Ecuadorian Amazon. Superimposed on the image is the ticker tape of stock prices and net change: CVX $\$ 134.12 \boldsymbol{\Delta}+63 \%$; Luis $\$ 4.24 \boldsymbol{\nabla}-89 \%$. And scattered across the entrance lawn were people holding framed posters of clear Plexiglas through which their faces appear behind the chalked commitment: "I will expose toxic polluting"; "I will expose over profiteering"; I will expose climate destruction"; I will expose Greenwashing" (Figs. 5 and 6).

Inside the stockholders' annual meeting, the founder of Amazon Watch, Attosa Soltani, together with individuals representing financial institutions, pension funds, and environmental and human rights organizations, confronted Chevron's CEO with questions raised in their jointly proposed shareholder resolution. Detailing in its preamble concern over Chevron's practices in Ecuador, Nigeria, and Burma, the resolution requests that the Board prepare a report "on the policies and procedures that guide Chevron's assessment of host country laws and regulations with respect to their adequacy to protect human health, the environment and our company's reputation." ${ }^{1}$ Now in its fifth year, this shareholder resolution reflects what some

\footnotetext{
1 Item 10 on the proxy card submitted to the U.S. Securities and Exchange Commission and with shareholders in advance of the 2009 Annual General Meeting on April 13, 2009.
} 


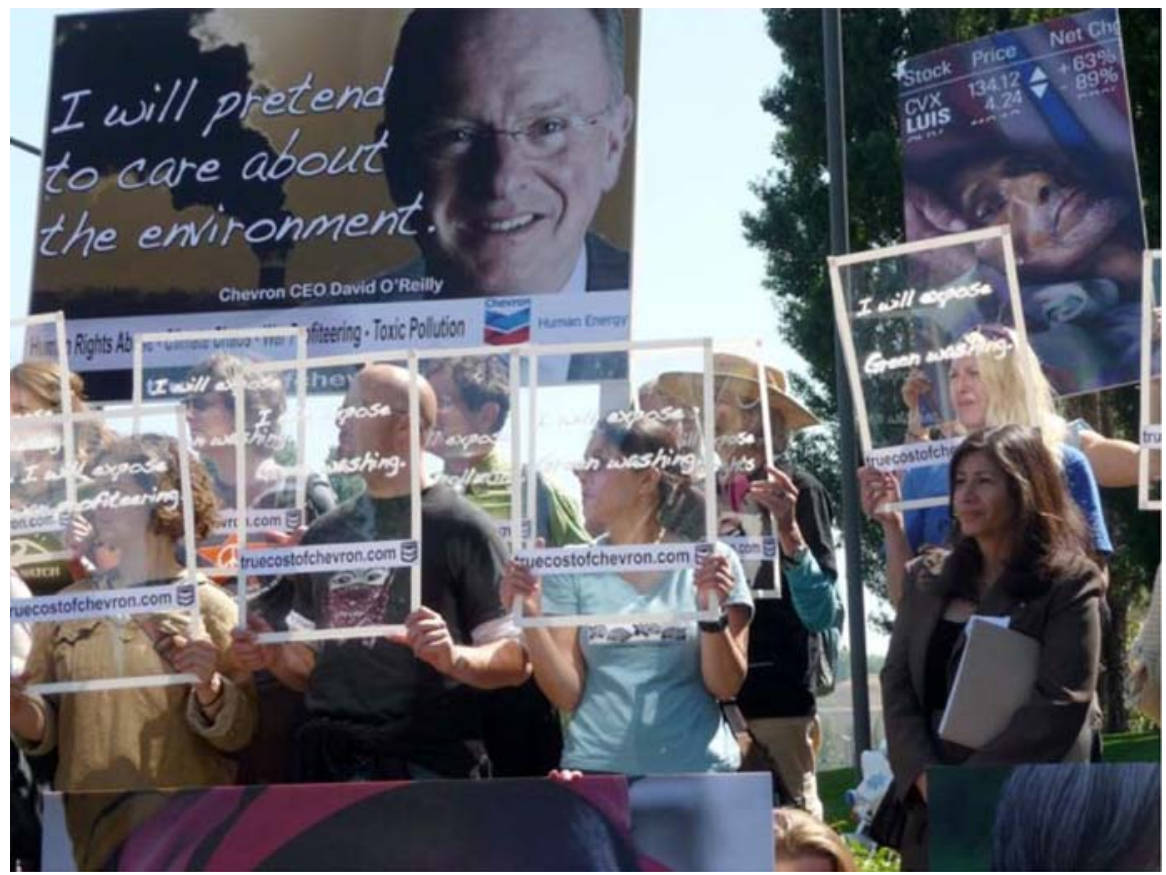

Fig. 5 Protestors redeploying the Chevron "Human Energy" print ads outside the corporation's 2009 AGM, Photo by Suzana Sawyer

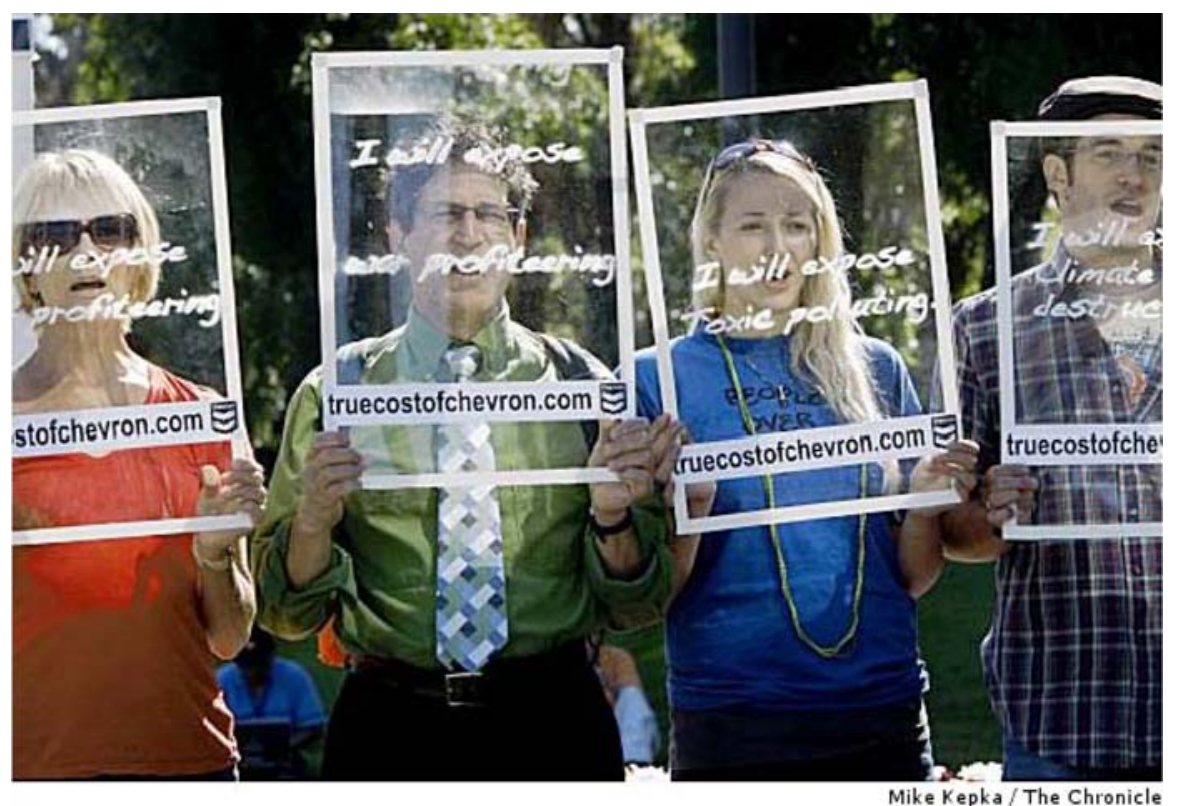

Fig. 6 More protestors outside Chevron's 2009 AGM, Photo by Mike Kepka 
call "share power" - a tactic that emerges from and engenders reflection on the entangled links through which we sustain and condone multinational corporations and their activities. Invoking proximity, convergence, and confrontation as tools that the corporate form legally grants them, shareholder activists seek to use the power of shares and their voice as investors to transform corporate activity. They seek to question specific corporate practices, to inform stockholders of their concerns, and challenge a corporate structure in which "owners" are largely passive to "managers." Theirs is a strategy of surfacing openings that emerge from involvement, tacit collusion, and responsibility.

Invoking forms of implication might muddle "the seductive clarity of denunciation" (Redfield 2005, p. 349), but it also allows for various attachments to a denunciatory stance-potentially compelling subversive relays in unanticipated ways. A web of affective registers exceeds Chevron's story, tantalizing with the promise that the confines of comfortable compromise-e.g., the inevitability of oil-might loosen. This is the immanence of possibility captured through engaging in entanglements. This is the power of human energy that Chevron never bargained for.

Open Access This article is distributed under the terms of the Creative Commons Attribution Noncommercial License which permits any noncommercial use, distribution, and reproduction in any medium, provided the original author(s) and source are credited.

\section{References}

Deleuze, Gilles. 2003. Francis Bacon: The logic of sensation. Minneapolis: University of Minnesota Press.

Foster, Robert J. 2007. The work of the "new economy": Consumers, brands and value. Cultural Anthropology 22(4): 707-731.

Redfield, Peter. 2005. Doctors, borders, and life in crisis. Cultural Anthropology 20(3): 330. 